DOI https://doi.org/10.30525/978-9934-26-047-6-27

\title{
ЕКОЛОГІЧНІ ПРОБЛЕМИ ПОВОДЖЕННЯ З МЕДИЧНИМИ ТА ФАРМАЦЕВТИЧНИМИ ВІДХОДАМИ
}

\author{
Сталінська I. B. \\ кандидат технічних наук, доцент, \\ доцент кафедри інженерної екологї міст \\ Харківський національний університет міського господарства \\ імені О. М. Бекетова \\ м. Харків, Украӥна \\ Хандогіна О. В. \\ старший викладач кафедри інженерної екологї міст \\ Харківський національний університет міського господарства \\ імені О. М. Бекетова \\ м. Харків, Украӥна
}

Проблема накопичення в навколишньому середовищі залишків лікарських засобів та їх метаболітів $\epsilon$ предметом вивчення багатьох дослідників в Україні та у країнах світу (Бардик Ю., Беловолченко Х., Бондарева Л., Дроздова О., Громовик Б., Н. Коваль, Ковпак Д., Койнова I., Косяченко К., Протс Н., Самаров I, Сердюк А., Сталінська I. та ін., (Ash R., Boyd G., Colborn T., Daughton C., Dumanoski D., Grimm D., Heberer T., Mauch B., Mitra S. Morgan M. Moulder W., Peterson M., Reemtsma H., Smith Ch.) [1 - 5].

Незважаючи на те, що фармацевтична продукція, належить до однієї iз найбільш специфічних категорій відходів, оскільки в разі неправильної утилізації наносить величезну шкоду оточуючому середовищу й здоров'ю людей, питання поводження з нею регулюється в Україні недостатньо, зокрема, $є$ вимоги лише щодо утилізації вакцин і прекурсорів, а також вимоги до поводження з медичними відходами, що утворюються в лікувально-профілактичних установах та інших закладах охорони здоров'я. Також відповідно до законодавчих норм певним чином налагоджені облік та утилізація відходів фармацевтичних заводів і фабрик як відходів виробництва. Варто зазначити, що офіційний облік відходів закладів охорони здоров'я в Україні відсутній, що унеможливлює належний моніторинг та контроль, також практично відсутня екологічно безпечна і економічно обгрунтована система поводження з відходами лікарняних установ. 
Згідно з Національною стратегією управління відходами в Україні до 2030 року [6], медичні відходи - це відходи, що утворюються в лікувально-профілактичних установах та інших закладах охорони здоров'я, що проводять медичні процедури, незалежно від форми власності, в установах і лікувально-профілактичних закладах санаторного лікування, аптеках, науково-дослідних інститутах і навчальних медичних закладах. Таким чином з законодавства про медичні відходи виключено неякісні лікарські засоби, що утворились не в лікарнях та подібних установах. В Базельській конвенції про контроль за транскордонним перевезенням небезпечних відходів та їх видаленням (1989 р.) [7], до якої Україна приєдналась у 1999 р., медичними відходами є відходи, що утворились у результаті лікарського догляду за пацієнтами в лікарнях, поліклініках та клініках; відходи виробництва i переробки фармацевтичної продукції; непотрібні фармацевтичні товари, ліки та препарати.

Щодо фармацевтичних відходів, то вчені виділяють окремо даний термін - це лікарські засоби та супутні товари, які надійшли до аптеки за легальними каналами збуту, але унаслідок будь-яких причин втратили свою відповідність вимогам нормативної документації та споживацьким характеристикам, а також лікарські засоби або їх упаковка, що повернуті споживачами до аптеки з метою їх знешкодження відповідно до принципів «зеленої фармації», і будь-які речовини, матеріали й предмети, що утворилися в процесі виготовлення ліків в умовах аптеки, які можуть створити небезпеку для навколишнього природного середовища, життя і здоров'я людини [8]. Фармацевтичні відходи включають відходи фармацевтичного виробництва, пляшки, флакони і будь-який забруднений лікарськими засобами матеріал та лікарські засоби, які $є$ непридатними для використання. Безсумнівно, такі відходи вимагають спеціальних методів поводження, що не мають негативного впливу на стан довкілля.

За даними 3МІ [9], в 2017 році обсяг продажів ліків становив 1,1 млрд упаковок, що становить понад 25 упаковок на кожного жителя країни щорічно. За обсягом аптечних продажів у грошовому вираженні лідирує група А «Засоби, що впливають на травну систему i метаболізм», далі йдуть групи С «Засоби, що впливають на серцевосудинну систему» $\mathrm{i} \mathrm{N}$ «Засоби, що діють на нервову систему». Лікарські препарати на українському ринку до споживача потрапляють двома шляхами: через заклади охорони здоров'я (лікарні, поліклініки, шпиталі тощо) та шляхом роздрібного продажу в аптеках. При цьому на госпітальний сегмент ринку приходиться всього близько $10 \%$ від загального обсягу продажів в Україні станом на 2018 рік у натуральному обчисленні [11]. Світова пандемія, яка розпочалася 108 
в 2020 році, суттєво збільшила кількість лікарських засобів, які використовуються населенням та обсяг інших медичних відходів (зокрема, потенційно небезпечні маски, рукавички тощо), що тільки загострює дану потребу та вимагає негайного реформування всієї системи поводження з медичними та фармацевтичними відходами.

Питання збору та знешкодження лікарських засобів, термін яких закінчився, або невикористаних ліків в Україні абсолютно не вирішене. Аптечні заклади та населення діють на власний розсуд та у напрямку найменших зусиль, зокрема, скидають протерміновані лікарські заклади до системи водовідведення, забезпечуючи розбавлення фармпрепаратів, чи видаляють у складі твердих побутових відходів. Незважаючи на рекомендацію до застосування Міністерством охорони здоров'я спільної настанови Всесвітньої організації охорони здоров'я та Міжнародної фармацевтичної федерації [11], в якій встановлено, що «...фармацевти повинні встановити безпечний спосіб утилізації відходів ліків у лікарні i/або аптеці громади, щоб заохочувати пацієнтів і громадськість повертати прострочені або непотрібні їм лікарські засоби і медичні пристрої...», в Україні діє заборона на повернення до аптечної мережі куплених лікарських засобів, що ускладнює створення єдиної системи збирання та утилізації медичних відходів.

Проведені дослідження щодо вивчення громадської думки по відношенню до шляхів утилізації медичних та фармацевтичних відходів, які утворюються в побуті, показало, що понад 51 \% опитаних викидають їх до твердих побутових відходів, що призводить до потрапляння небезпечних компонентів на полігони та звалища, понад 23 \% виливають (висипають) такі відходи в каналізацію, що несе ризик забруднення водних об’єктів, 14 \% - спалюють такі відходи, $10 \%$ кладуть поруч з урною чи контейнером для ТПВ [12]. На нашу думку, ця проблема обумовлена необізнаністю населення щодо поводження 3 побутовими МВ, складністю проведення моніторингу цих речовин та украй обмеженими фінансовими ресурсами та відсутністю будь-яких механізмів збору та знешкодження протермінованих або невикористаних лікарських засобів від населення. До того ж, вся законодавча база України в сфері поводження з небезпечними МВ носить статичний (без вказівки чітких цілей і термінів їх виконання); та декларативний (без чітких механізмів реалізації та механізмів контролю) характер. Слід відмітити, що у Національній стратегії управління відходами України до 2030 року наголошується на існуючій проблемі поводження 3 MB, але не вказані конкретні стратегії та інструменти щодо іiі розв'язання.

На нашу думку, для подолання проблеми, пов'язаної з утворенням та потраплянням в довкілля великої кількості медичних та фарма- 
цевтичних відходів, необхідне створення комплексної системи управління, яка забезпечить удосконалення законодавчо-нормативної бази, підвищення обізнаності як фахівців, що працюють в даній сфері, так i широких верств населення, створення інфраструктури (пунктів збирання, потужностей з утилізації та знешкодження), забезпечення обліку утворення медичних та фармацевтичних відходів та контроль за виконанням законодавчо-нормативних вимог тощо.

\section{Література:}

1. Drozdova, O. O., Bondareva, L. V. (2015). Do pytannia utylizatsii ta zneshkodzhennia farmatsevtychnykh vidkhodiv v Ukraini. Retrieved from: http://dspace.nuph.edu.ua/bitstream/123456789/11954/1/348-349\%28 1\%29.pdf. [in Ukrainian].

2. Сталінська I. В. Проблеми екологічної безпеки утилізації медичних відходів. Науковий вісник Національного лісотехнічного університету України. Львів, 2018. Том 28 № 2, С. 91-94.

3. Daughton C.G. Illicit Drugs: Contaminants in the environment and utility in forensic epidemiology // Reviews of Environmental Contamination and Toxicology / Ed. Whitacre. Springer, 2011.- P. 59-110

4. Boyd GR, Reemtsma H, Grimm DA, Mitra S. Pharmaceuticals and personal care products (PPCPs) in surface and treated waters of Louisiana, USA and Ontario, Canada // Sci. Total. Environ. -2003. -V. 311. №1-3. - P. 135-149.

5. Carucci A., Coppai G., Piredda M. Biodegradability and toxicity of pharmaceuticals in biological wastewater treatment plants // Journal of Environmental Science and Health Part A. 2006. -Vol.41.- P. 1831-1842.

6. Національна стратегія управління відходами в Україні до 2030 року. База даних «Законодавство України». BP України. URL: https://zakon.rada.gov.ua/laws/show/820-2017-\%D1\%80

7. Базельська конвенція про контроль за транскордонним перевезенням небезпечних відходів та їх видаленням URL: https://zakon.rada.gov.ua/laws/show/995_022\#Text

8. Панфілова Г.Л., Гала Л.О. Поводження 3 фармацевтичними відходами як важлива складова ефективної реалізації соціальної функції аптек за умов впровадження належної аптечної практики. Соціальна фармація в охороні здоров'я, 2018. Т. 4. № 1. С. 40-52. URL: http://91.234.42.22/bitstream/123456789/15828/1/40-52.pdf

9. ТОП-10 найбільш продаваних ліків у 2017 році в Україні. Інформаційний портал «Хронограф». URL: http://hgraf.com.ua/ index.php/joomla-pages/login-form/item/10226-top-10-najbilshprodavanikh-likiv-u-2017-rotsi-v-ukrajini 
10. Кулицький С. Фармацевтична галузь і фармацевтичний ринок в Україні: стан і проблеми розвитку URL: http://www.nbuviap.gov.ua/ index.php?option=com_content $\&$ view=article \&id=4227:rinok-likarskikhzasobiv-v-ukrajini- $2 \&$ catid $=8 \&$ Itemid $=350$

11. Належна аптечна практика: Стандарти якості аптечних послуг (Спільна настанова МФФ/ВООЗ з НАП) URL: https://zakon.rada.gov.ua/ rada/show/897_009\#n2

12. Сталінська I. В., Абазін О. Зниження екологічного ризику при поводженні з побутовими медичними відходами. Вісник Національного університету водного господарства та природокористування. Технічні науки. Рівне, 2020. Випуск 1 (89), С. 74-83.

DOI https://doi.org/10.30525/978-9934-26-047-6-28

\title{
CURRENT PROBLEMS AND PROSPECTS OF MOLLUSCS FISHING IN THE NORTHWESTERN PART OF THE BLACK SEA
}

\author{
Shekk P. V. \\ Doctor of Agricultural Sciences, Professor, \\ Head of the Aquatic Bioresources and Aquaculture Department \\ Odesa State Environment University \\ Burhaz M. I. \\ Candidate of Biological Sciences, \\ Associate Professor at the Aquatic Bioresources and Aquaculture \\ Department \\ Odesa State Environment University
}

Matviienko T. I.

Senior Lecturer at the Aquatic Bioresources and Aquaculture Department Odesa State Environment University

Odesa, Ukraine

In recent decades, the ecosystem of the northwestern Black Sea has undergone significant changes under the influence of anthropogenic factors, which are accompanied by a decrease in the bioresources at all trophic levels and in the biodiversity in general, which in turn reduces catching the main fishery objects. There is a transformation in the extraction of aquatic 